\title{
The Effect of Sugarcane Bagasse and Filter Mud Compost Fertilizer and Manure Application on the Growth and Production of Sugarcane Rahmad $^{1}$, Laode Asrul ${ }^{2}$, Tutik Kuswinanti ${ }^{3}$, Yunus Musa ${ }^{4}$
}

\author{
${ }^{*}$ Doctoral Student, Graduate Program of Hasanuddin University, Makassar, Indonesia \\ ${ }^{2}$ Department of Agrotechnology, Faculty of Agriculture, Hasanuddin University, Makassar, South Sulawesi, \\ Indonesia \\ ${ }^{3}$ Department of Agrotechnology, Faculty of Agriculture, Hasanuddin University, Makassar, South Sulawesi, \\ Indonesia \\ ${ }^{4}$ Department of Agrotechnology, Faculty of Agriculture, Hasanuddin University, Makassar, South Sulawesi, \\ Indonesia
}

\begin{abstract}
Sugarcane requires land conditions that contain high organic matter to support growth and production. Giving compost from the results of the utilization of the byproducts of sugarcane processing in the form of bagasse and filter mud is expected to increase the sugarcane productivity. The purpose of this study was to determine the effect of compost from the sugarcane bagasse, filter mud and cow manure using the decomposer and Trico Plus mushroom consortium on the growth and production of sugarcane. The experiment was carried out in the form of a randomized block design consisting of eight treatments and three replications. Each treatment was applied as much as 15 tons per hectare, NPK basic fertilizer for all $350 \mathrm{~kg}$ treatments per hectare. The results showed that the treatment of compost provides a higher number of sugarcane saplings compared to without the provision of compost. The compost $\mathrm{C}$ treatment gave the highest number of sugarcane saplings and the highest number of segments of 7.45 sugarcane saplings and 18.33 segments. Treatment $G$ gave the highest plant height of $283.30 \mathrm{~cm}$, treatment B gave the highest segment length of $15.17 \mathrm{~cm}$, stem diameter of $2.62 \mathrm{~cm}$, stem height of $163.00 \mathrm{~cm}$, sugarcane stem weight of $158.36 \mathrm{~kg}$ per plot and 97.655 tons per hectare and POL value $31.32 \%$ while treatment $\mathrm{E}$ gave the highest Briks value of $23.43 \%$. G treatment gave the best plant height value of $283.30 \mathrm{~cm}$. Giving compost from the results of mixing bagasse, filter mud and manure using the mushroom and Trico Plus consortiums gave better results on growth, and production of sugar cane compared to without the provision of compost.
\end{abstract}

Keywords: Compost, Sugarcane Bagasse, Filter Mud, Manure

\section{INTRODUCTION}

Sugarcane has a strategic value because it is a sugarproducing plant that is much needed by the people of Indonesia. The need for sugar every year will continue to increase along with the increase in population and industrial needs that need sugar in the production process.

The increasing need for sugar must always be balanced with the availability of sugar in the country. One effort that can be done is to increase the production of sugarcane so that sugar production can increase. Seeing the importance of sugarcane, the 
efforts to increase production are always sought, but it is not easily increased because it is influenced by many factors including the land fertility.

The intensive use of sugarcane plantations every year results in reduced land fertility. The land fertility can no longer be maintained because the ability of land to provide nutrients continues to decline (Shulka et al.2016). Chemical fertilization of N, P and $\mathrm{K}$ is no longer able to sustain the optimal production. This is likely due to physical, chemical and biological problems occurring in sugarcane plantations.

Land fertility is a medium where the growth of sugarcane plants is needed to support the growth and production of sugarcane plants optimally. Provision of organic material in sugarcane planting land is one of the efforts to improve the quality of the land both physically, chemically and biologically.

Sugarcane bagasse and filter mud are by-products of sugar mill processing that can be used to increase organic material on the ground and provide benefits for the soil and plants. There are big amount of bagasse and filter mud that can be utilized by the Sugar Factory to support increased sugarcane production by using it as compost that can be applied to the field.

Application of compost from sugarcane bagasse and filter mud continues to be assessed to determine its effect. A study was carried out to determine the effect of compost from bagasse and compost made from a decomposer or a single fungus Trico Plus.

\section{METHODS}

The compost used in this research is fertilizer produced from composting various compositions of bagasse, filter mud and manure mixes using a decomposer and Trico Plus mushroom consortium which has been tested for maturity and nutrient content (test results are not published in this journal).

This experiment was carried out in the Pangkep State Agricultural Polytechnic experimental plantation. The experiment was in the form of a randomized block design (RBD) consisting of 8 treatments as described below:

$A=$ Compost from a mixture of bagasse with manure (1: 1) using a mushroom consortium of 15 tons per hectare $+350 \mathrm{~kg}$ of NPK inorganic fertilizer per hectare

$\mathrm{B}=$ Compost from bagasse mixture with manure (1: 1) using Trico Plus as much as 15 tons per hectare $+350 \mathrm{~kg}$ of NPK inorganic fertilizer per hectare

$\mathrm{C}=$ Compost from a mixture of bagasse, filter mud and manure (1: 1: 1) using a mushroom consortium of 15 tons per hectare $+350 \mathrm{~kg}$ of NPK inorganic fertilizer per hectare

$\mathrm{D}=$ Compost from a mixture of bagasse, filter mud and manure (1: 1: 1) using the Trico Plus consortium of 15 tons per hectare $+350 \mathrm{~kg}$ of NPK inorganic fertilizer per hectare

$\mathrm{E}=$ Compost from a mixture of filter mud and manure (1: 1) using a mushroom consortium of 15 tons per hectare $+350 \mathrm{~kg}$ of NPK inorganic fertilizer per hectare

$\mathrm{F}$ = Compost from a mixture of filter mud and manure (1: 1) using Trico Plus as much as 15 tons per hectare $+350 \mathrm{~kg}$ of NPK inorganic fertilizer per hectare

$\mathrm{G}=$ Filter mud without composting as much as 15 tons per hectare $+350 \mathrm{~kg}$ of NPK inorganic fertilizer per hectare

$\mathrm{H}$ = Without compost and given NPK inorganic fertilizer as much as $350 \mathrm{~kg}$ per hectare

Each treatment was repeated three times so that there were 24 units of the experimental plot. The area per unit was $4 \mathrm{~m} \times 4 \mathrm{~m}$. Variance results (ANOVA) 
which were significantly different were continued with the Duncan test $(<0.05)$. Observation parameters consisted of the number of sugarcane saplings, plant height, number of segments, length of segments, stem diameter, stem height, weight per meter, weight per hectare, Brix and POL.

\section{III.RESULTS AND DISCUSSION}

\section{A. Number of sugarcane saplings}

The results of analysis of variance showed that the treatment did not have a significant effect on the number of sugarcane saplings. Based on Figure 1, it shows that treatment $\mathrm{C}$ shows the highest number of saplings as many as 7.45 saplings while treatment A gives the lowest number of saplings as many as 5.67 .

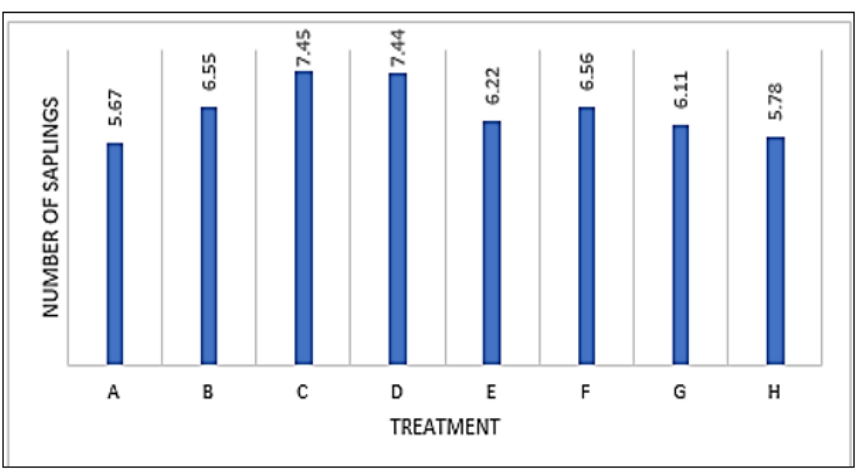

Figure 1. The average number of sugarcane saplings 32 weeks after planting

This is in line with the research of Endriyana et al. (2016). The application of organic fertilizer gave no significant difference and gave better results on the number of saplings of sugarcane compared to without organic fertilizer. Guntoro, et al. (2003), the nutrient content of $\mathrm{P}$ in organic fertilizer will increase the number of sugarcane saplings to the optimum dose and will decrease if the dose is increased.

The results of research by Elsyade et.al (2008) showed that the administration of nitrogen fertilizer and filter mud did not have a negative effect on sugarcane germination. In addition, the availability of NPK inorganic nutrients provided will support the availability of nutrients especially $\mathrm{N}, \mathrm{P}$, and $\mathrm{K}$ which encourage the formation of more active saplings (Kuntohartono, 1999). Filter mud has nitrogen and phosphorus content that is easily available (Dotaniya et al.2013).

The number of saplings is largely determined by the nutrient content found in the soil. Providing compost adds nutrients needed by sugarcane. The number of saplings was greater in the treatment of compost compared to control treatment because of the availability of nutrients needed by sugarcane. This is according to what Clements (1980) stated that the vegetative growth phase of sugarcane plants will absorb nutrients more actively. In sugarcane, optimal nutrient absorption is at the age of 90 days or more.

\section{B. Plant Height}

The results of analysis of variance showed that the treatment did not have a significant effect on the height of sugarcane at week 32 after planting. Figure 2 shows that treatment $G$ gave the best plant height of $282.23 \mathrm{~cm}$ while treatment $\mathrm{E}$ gives the lowest plant height of $120.67 \mathrm{~cm}$.

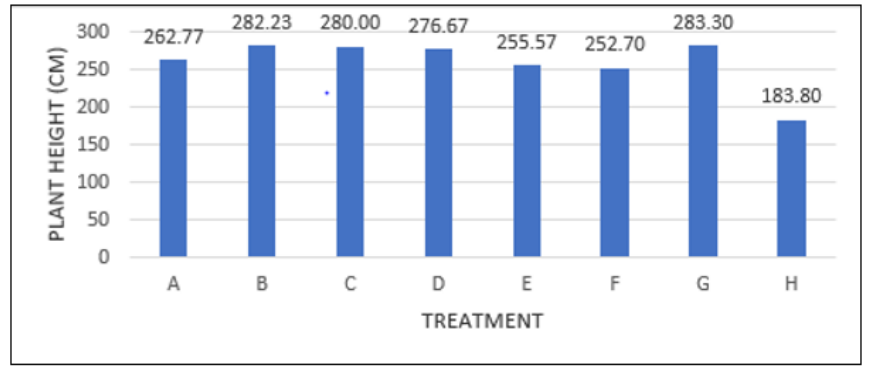

Figure 2. Sugarcane plant height $(\mathrm{cm}) 32$ weeks after

$$
\text { planting }
$$

The growth process of sugar cane plants requires sufficient nutrients. If one nutrient is reduced, it will affect growth. Nutrients needed for plant height are the nutrient elements of $\mathrm{N}, \mathrm{P}$ and $\mathrm{K}$. 
Filter mud can be used to improve soil properties, and it contains nutrients of $\mathrm{N}, \mathrm{P}, \mathrm{k}, \mathrm{Ca}, \mathrm{Mg}$ and $\mathrm{SO} 4$ (Devarajan et al. 1996). Furthermore, the results of research by Guntoro et al. (2003) found that bagasse compost fertilizer combined with cow dung contains $1.12 \% \mathrm{~N}, 0.1 \% \mathrm{P} 2 \mathrm{O} 5,0.008 \% \mathrm{~K} 2 \mathrm{O}$ and $0.02 \% \mathrm{~S}$ (SO4).

This is in accordance with the research of Mulyadi (2000) that the administration of filter mud can significantly influence the increase in the vegetative phase of sugarcane growth such as an increase in the length of the sugarcane stem.

\section{The number and length of sugarcane segment and the stem diameter}

The results of analysis of variance showed that the treatment did not have a significant effect on the number of segments, length of segment and stem diameter. Based on Figure 3, treatment $B$ gave the highest plant height of $282.23 \mathrm{~cm}$ and stem height of $148.67 \mathrm{~cm}$ while treatment $\mathrm{H}$ gave the lowest plant height of $183.80 \mathrm{~cm}$. Treatment $\mathrm{E}$ gave the lowest stem height of $120.67 \mathrm{~cm}$.

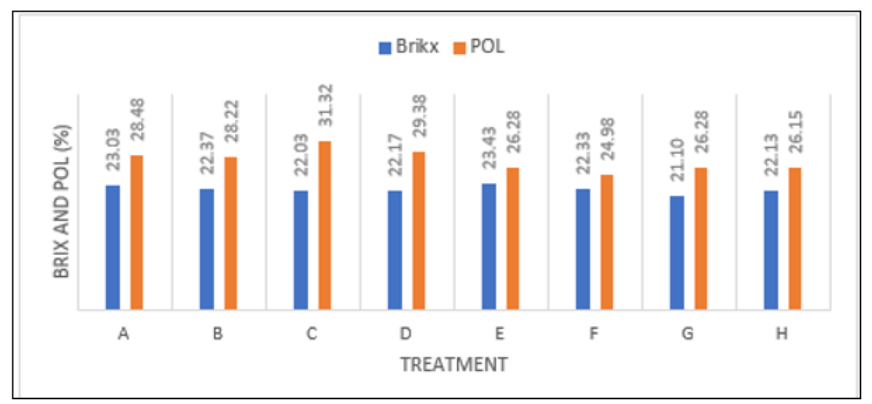

Figure 3. Number of segment, length of segment, and diameter stem 32 weeks after planting

This is in line with research of Endriyana et al. (2016) which showed that the application of organic fertilizer has a significant different effect and gives better results on the diameter of the stem, and the number of leaves of sugarcane compared to without the application of organic fertilizer. The results of Cahyani et al. (2016) study showed that the combination treatment of organic fertilizer and inorganic fertilizer did not have a significant effect on the diameter of ratoon sugarcane stem.

The availability of sufficient nutrients is an environmental factor that determines the growth rate of plants (Gardner et al., 1985).If the availability of nutrients that are sufficient and balanced, the process of cell division and enlargement takes place quickly which results in the rapid plant organs growth thereby increasing the rate of plant growth (Mutryarny et al. 2014).

\section{Stem Height}

The results of analysis of variance showed a significant effect on the height of sugarcane stems 32 weeks after planting (MST). Based on the table, treatment $B$ gave the highest height of sugarcane stem of $163 \mathrm{~cm}$ and not significantly different from treatment $\mathrm{C}$, but significantly different from treatment A, D, E, F, G and H. Treatment B gave the highest stem height of $163.00 \mathrm{~cm}$ and the lowest was treatment $\mathrm{H}$ which had $139.67 \mathrm{~cm}$ of stem height.

Table 1. Average Height of Sugarcane Stem 32 weeks after planting

\begin{tabular}{|c|c|}
\hline Treatment & Average \\
\hline A & $141.00^{\mathrm{a}}$ \\
\hline B & $163.00^{\mathrm{c}}$ \\
\hline C & $160.00^{\mathrm{c}}$ \\
\hline D & $148.75^{\mathrm{b}}$ \\
\hline E & $145.50^{\mathrm{ab}}$ \\
\hline F & $148.50^{\mathrm{b}}$ \\
\hline G & $151.25^{\mathrm{b}}$ \\
\hline H & $139.67^{\mathrm{a}}$ \\
\hline
\end{tabular}

The result of this result is in line with the research by Endriyana et al. (2016). She found that organic fertilizer gave significantly different effect and better yields on the height and dry weight of sugarcane 
compared to without organic fertilizer. The results of this study also in line with the research of Cahyani et al. (2016) which found that the combination of organic fertilizer and inorganic fertilizer did not provide a significant effect on the sugarcane stem height and leave length.

Giving bagasse and filter mud will increase the availability of $\mathrm{P}$ element in the soil and the availability of various organic acids (Datta and Gupta, 1983), and mobilize the $P$ element so that it is easily available to plants (Dotaniya et al., 2013). The presence of nutrients found in the compost fertilizer helps the availability of nutrients for plants' growth.

The weight of sugarcane is often a problem in the sugarcane industry today because the weight of sugarcane is one of the factors determining the sugarcane crystals. Sugarcane weight is also positively correlated with the stem diameter and stem height. The bigger the diameter of the stem and the longer the height of the stem, the greater the sugarcane weight obtained.

\section{E. Number of sugarcane stem}

The results of analysis of variance showed that the treatment had no significant effect on the number of sugarcane stems. Figure 4 shows that treatment B gives the highest number of sugarcane stems per clump as many as 4.40 pieces and the lowest was treatment $\mathrm{H}$ which produced 3.61 pieces.

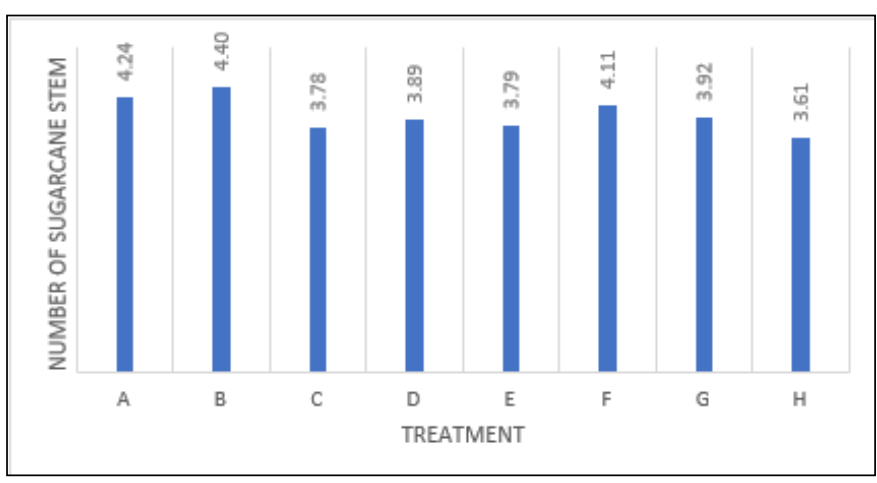

Figure 4. Number of sugarcane stem 32 weeks after planting
Observation of stem height, number of stems and weight of stems greatly determines the weight of sugarcane per meter in the field. As Sumantri (1989) said, the components of plant growth determining the yield of sugarcane are the height of the stem, number of stems, and diameter of the stem. The main contribution to the yield is the sugarcane weight. Elsyade et.al (2008) administration of filter mud and nitrogen fertilizer increases the $\mathrm{C}$ component of soil and nitrogen, increases sugarcane yield and number of stems compared to the control treatment.

In treatment B which is compost from the mixture of bagasse and manure gave the highest weight. This is because compost fertilizer given in addition to containing nutrients also contains decomposing microbes that can help plant growth. Trico plus is a decomposer product of the Trichoderma Harsianum fungus that functions as a decomposer as well as controlling disease of pathogens and producing hormones for growth. This can be seen from all the compost given in treatments $\mathrm{B}, \mathrm{D}$ and $\mathrm{F}$ from those using Trico Plus as the active ingredient for compost, which gave a better weight than the other treatments. This is in line with research of the provision of filter mud of 4 tons per hectare combined with the administration of $5 \mathrm{~kg}$ of Azotobacter per hectare to increase the yield of sugarcane and sugar (Tiwari and Nema 1999).

The application of compost underground increases the supply of organic $\mathrm{C}$ and $\mathrm{N}$ for microbial communities, improves the nutrient recycling process, soil environmental conditions and soil health for sugarcane growth and thereby increases sugarcane productivity (Shaarani et al. 2019).

\section{F. Sugarcane weight}

The results of analysis of variance showed that the treatment did not have a significant effect on the weight of sugarcane. The weight of sugarcane was 
calculated from the amount of weight produced by sugarcane per meter and then converted to hectares. The weight of sugar cane is greatly influenced by the number of sugarcane stems per meter, stem height and stem diameter. The analysis of variance showed that the treatment did not significantly affect the weight of sugarcane per hectare. Figure 5 shows the treatment of compost is better than without compost. Treatment B gave the highest weight per plot of $158.36 \mathrm{~kg}$ and $97,655 \mathrm{~kg}$ per hectare compared to other treatments and treatment $\mathrm{H}$ gave the lowest sugarcane weight per plot of $129.92 \mathrm{~kg}$ and per hectare of $80,117 \mathrm{~kg}$.

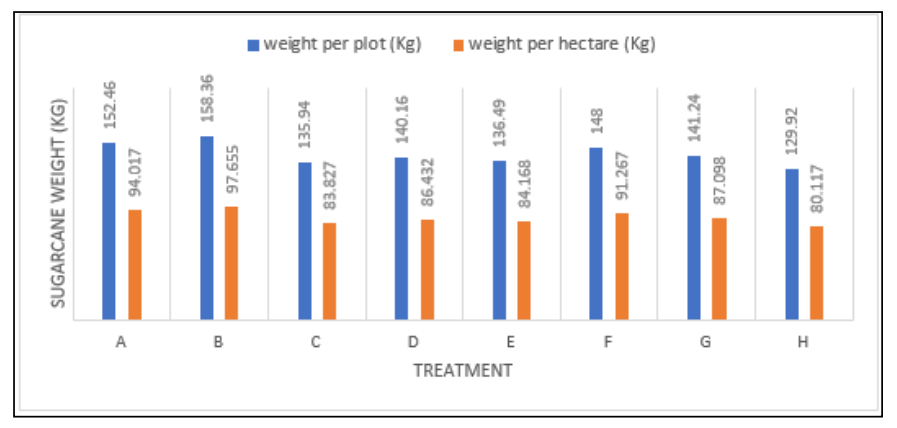

Figure 5. Weight per plot and per hectare of sugarcane 32 weeks after planting

The results of this study are in line with the research results of Dotaniya et al. (2016) that the use of sugarcane bagasse and filter mud to the soil improves the soil chemical, physical and biological properties and improves the quality and yields. The use of filter mud is able to increase sugarcane production without having a detrimental effect on quality and the environment (Kornodofer and Anderson, 1997). The use of filter mud compost of 10-15 tons per hectare with chemical fertilizer of NPK increases the sugarcane yield and cane sugar by $21 \%$. (C. Shankariah and K.N Kalyana Murthy.2005).

\section{G. Brix and Pol (\%)}

The analysis showed that the treatment did not have a significant effect on the value of Brix and Pol. Figure 6 shows the brix value of sugarcane in all treatments is in the range of $21.10-23.43 \%$, while for the POL value of sugarcane is in the range of 26.15$31.32 \%$. Treatment A gave the highest Brix value of $23.03 \%$ and treatment $G$ gave the lowest Brix value of $21.10 \%$ and treatment $\mathrm{D}$ gave the highest POL value of $31.32 \%$ and the lowest POL value was in treatment F which was $24.98 \%$.

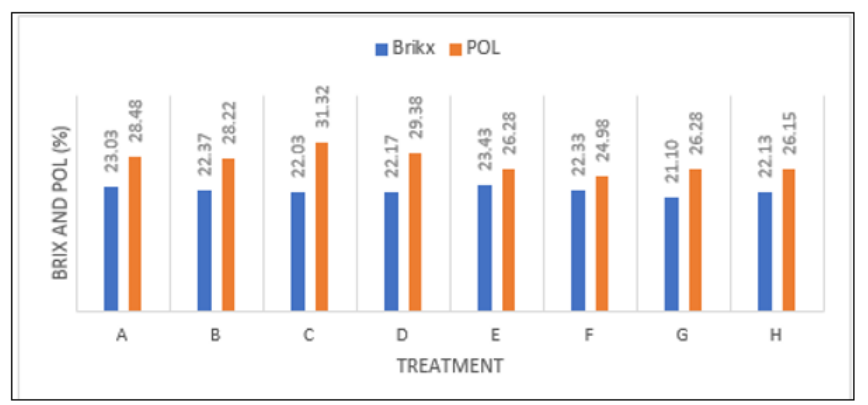

Figure 6. Brix and POL value (\%) of sugarcane 32 weeks after planting

The observations on the brix value indicate that the treatment gives results that are not significantly different. The measurement results of sugarcane Brix value 32 weeks after planting for all treatments are already above $20 \%$. It shows that the sugarcane plant has entered the maturation phase.

The value of POL which is the value of sucrose content in sugarcane stems, shows the effect of the treatment has no significant effect. Treatment C giving compost from a mixture of bagasse, filter mud and cow manure gave the highest POL value compared with no compost fertilizer application. This POL value shows the percentage of sugar content in sugarcane stems.

The results of this study are in accordance with the research of Bangar et al. (2000) and Sharma et al. (2002). Nitrogen fertilizer and filter mud were able to 
improve dry matter, sugarcane production and sugar. Different result was found by R. P. Viator et al. (2002) Composting did not affect sugarcane yield compared to the control treatment. The application of filter mud and Triple Superphosphate increases the maximum concentration of $\mathrm{P}$ in the leaves, increase the production of sugarcane stems, sugar production and Brix (Vasconcelosa et al., 2017).

\section{IV.CONCLUSION}

1. Giving compost to sugarcane plants gives better growth and production compared to without giving compost

2. Giving compost from a mixture of bagasse and manure with the use of Trico Plus as a decomposer gives higher sugarcane weight

3. Giving compost from a mixture of bagasse, filter mud and manure by using a fungus consortium as a decomposer gives higher sugar production

\section{REFERENCES}

[1]. Endriyana Putra, Albertus Sudirman, and Wiwik Indrawati.2016. The Effect of Organic Fertilizer on the Vegetative Growth of Sugarcane Variety of GMP 2 and GMP 3. AIP Journal Volume 4 No. 2.: 60-68

[2]. Suci Cahyani, Albertus Sudirman, and Abdul Azis. The Response of Vegetative Growth of Sugarcane Ratoon 1 (Saccharum officinarum L.) by Giving Combination of Organic and Inorganic Fertilizers. AIP Journal Volume 4 No. 2 | October 2016: 69-78

[3]. Mutryarny, E., Endriani., and U. S. Lestari. 2014. The Utilization of Rabbit Urine to Increase Growth and Production of Mustard Greens (Brassica juncea L.) of Tosakan Variety.
[4]. Gardner, F.P., B.R. Pearch, and L.M. Roger. 1985. Physiology of Crop Plant. The Lowa State University Press. Iowa.

[5]. Bangar KS, Parmar BB, Maini A (2000) Effect of nitrogen and press mud application on yield and uptake of N, P and K by sugarcane (Saccharum officinarum L.). Crop Res 19(2):198-203

[6]. Dotaniya ML (2013) Impact of various crop residue management practices on nutrient uptake by rice-wheat cropping system. Curr Adv Agric Sci 5(2):269-271

[7]. Viator RP, Kovar JL, Hallmark WB (2002) Gypsum and compost effects on sugarcane root growth, yield, and plant nutrients. Agron J 94:1332-1336

[8]. Sharma BL, Singh S, Sharma S, Prakash V, Singh RR (2002) Integrated response of press mud cake and urea on sugarcane in calcareous soil. Cooperative Sugar 33(12):1001-1004

[9]. Korndorfer GH, Anderson DL (1997) The use of impact of sugar alcohol residues of vinasse and filter cake on sugarcane production in Brazil. Sugar Azucar 92:30-35

[10]. Tiwari RJ, Nema GK (1999) Response of sugarcane (Saccharum officinarum) to direct and residual effect of press mud and nitrogen. Indian J Agric Sci 69:644-646

[11]. Devarajan L, Ramanathan G, Oblisami G (1996) Studies on the performance of sugarcane varieties with distillery effluent irrigation. In: National symposium on "Use of distillery and sugar industry wastes in agriculture" held on 28-29, October

[12]. Clements, H. S. 1980. Sugarcane Crop Logging and Crop Control, Principles and Practices. University Press of Hawai. Honolulu

[13]. Guntoro, D., Purwono, dan Sarwono. 2003. The effect of bagasse compost on the nutrient uptake and growth of sugarcane (Saccharum officinarum L.). Bul. Agron. 31(3): 112-119. 
[14]. M.T. Elsayed, M.H. Babiker, M.E. Abdelmalik, O.N. Mukhtar D. Montange d, Impact of filter mud applications on the germination of sugarcane and small-seeded plants and on soil and sugarcane nitrogen contents. Bioresource Technology 99 (2008) 4164-4168

[15]. C. Shankariah and K.N. Kalyana Murthy. 2005. Effect of Enriched Pressmud Cake on Growth, Yield and Quality of Sugarcane.Sugar Tech. 7(2\&3) : 1-4

[16]. Ricardo de Lima Vasconcelosa, Hilário Júnior de Almeidaa, Renato de Mello Pradoa, Luiz Flávio José dos Santosb, João Martins Pizauro Júniorb.Filter cake in industrial quality and in the physiological and acid phosphatase activities in cane-plant. Industrial Crops \& Products 105 (2017) 133-141

[17]. Shalyda Md Shaarani, Nor Jannah Mokhtar1, Zatul Iffah Mohd Arshad, Rohaida Che Man1, Siti Kholijah Abdul Mudalip1 and Siti Zubaidah Sulaiman. Co-composting landfill leachate with sugarcane bagasse for biofertilizer production. AIP Conference Proceedings 2124, 020032 (2019); https://doi.org/10.1063/1.5117092

[18]. Datta M, Gupta RK (1983) Utilization of press mud as amendment of acid soil in Nagaland. J Indian Soc Soil Sci 31:511-516

[19]. Shukla SK, Yadav RL, Awasthi SK, Gaur A (2016) Soil microbial biomass nitrogen, in situ respiration and crop yield influenced by deep tillage, moisture regimes and $\mathrm{N}$ nutrition in sugarcane-based system in subtropical India. Sugar Tech. doi:10.1007/s12355-016-0442-1

[20]. Topani,K., Sisawanto, B. and Suntari, R. 2015. The effect of application of soil organic fertilizer on soil chemical properties, and the growth and production of sugarcane in the experimental garden of Bone Sugar Factory, Bone Regency. Journal of Land and Land Resources 2(1), 155162.
[21]. Sumantri, A. 1989. The Interaction of Sugarcane Varieties and Planting Period in Jatiroto Sugar Factory Field. Proceedings of the Seminar on Dry Land Cultivation. Pasuruan.428 - 435.

[22]. Kuntohartono, T. 1999. Sugarcane Germination. Indonesian Sugar. 24 : 11-15.

[23]. Mulyadi, M. 2000. The study on the application of filter mud and steel slags in the kandiudox land of Pelaihari in an effort to improve the chemical properties of the soil, $\mathrm{N}, \mathrm{Si}, \mathrm{P}$ and $\mathrm{S}$ uptake and sugarcane growth. Thesis of Bogor Agricultural Institute.

[24]. M. L. Dotaniya, S. C. Datta, D. R. Biswas, C. K. Dotaniya, B. L. Meena,S. Rajendiran, K. L. Regar, Manju Lata. Use of sugarcane industrial by-products for improving sugarcane productivity and soil health. Int J Recycl Org Waste Agricult (2016) 5:185-194.DOI 10.1007/s40093-016-0132-8

\section{Cite this article as :}

Rahmad, Laode Asrul, Tutik Kuswinanti, Yunus Musa, "The Effect of Sugarcane Bagasse and Filter Mud Compost Fertilizer and Manure Application on the Growth and Production of Sugarcane", International Journal of Scientific Research in Science and Technology (IJSRST), Online ISSN : 2395-602X, Print ISSN : 2395-6011, Volume 6 Issue 6, pp. 338-345, November-December 2019. Available at doi : https://doi.org/10.32628/IJSRST196668 Journal URL : http://ijsrst.com/IJSRST196668 